\title{
The AIPO Society: Present and Future Trends
}

\author{
María Paula González ${ }^{1,2}$, Toni Granollers ${ }^{2}$, Cesar A. Collazos ${ }^{3}$, and Julio Abascal ${ }^{4}$ \\ ${ }^{1}$ CONICET (National Council of Scientific and Technical Research) and \\ Department of Computer Science \& Eng. - Universidad Nacional del Sur, Argentina \\ mpg@cs.uns . edu .ar \\ ${ }^{2}$ GRIHO Research Group - Universitat de Lleida, Spain \\ \{mpg, tonig\} adiei.udl. cat \\ ${ }^{3}$ Department of Systems - Universidad del Cauca. FIET-Sector Tulcan, Popayán, Colombia \\ ccollazo@unicauca.edu.co \\ ${ }^{4}$ Informatika Fakultatea. University of the Basque Country, Spain \\ julio.abascalesi.ehu.es
}

\begin{abstract}
This paper presents an overview of the international Asociación Interacción Persona-Ordenador (AIPO), a growing society related to HCI and focused on the Spanish-speaking community. AIPO is aimed to support HCI related activities both in the academia and the industry, connecting hundreds of millions of potential members.
\end{abstract}

\section{Looking to the Present: The AIPO Scope and Main Activities}

Since 1999 the Asociación Interacción Persona Ordenador (AIPO) ${ }^{1}$ has covered a wide spectrum of activities to promote HCI in the Spanish-speaking community. ${ }^{2}$ Indeed, AIPO is a multidisciplinary society oriented towards people whose cultural background is primarily associated with the Spanish language and culture, regardless of ethnic and geographical differences. The AIPO society is open to everyone belonging to the above community. Their members are mainly university researchers specialized in HCI, doctoral students focused on HCI, and HCI-related professionals coming from the industry.

In the last decade, main AIPO activities were articulated through three axis: enhancing HCI education, promoting the integration of the industry and the academia in common projects around HCI, and studing an appropriate translation of international ideal values and standards associated with usability to the Spanishspeaking context of use. To enhance HCI education, AIPO has focused on analysing the state of the art of HCI proposals in Spanish-speaking universities[1]. Besides, a series of HCI-related academic events were sponsored, such as the 5th, 6th and 7th editions of the Congreso Internacional de Interacción Persona Ordenador (International Conference on HCI) held in 2004, 2005 and 2006 respectively; and the I Jornadas de Trabajo sobre Enseñanza de CHI (1st. Symposium on CHI Education) in 2005. A series of HCI-related books were published [2,3,4,5,6]. With respect to

\footnotetext{
${ }^{1}$ See www.aipo.es (webpage of the Asociación Interacción Persona Ordenador - AIPO).

${ }^{2}$ Note that this community is formed by inhabitants of Spain and all Spanish-speaking countries in North, Central and South America, including almost 35 million people living in the USA with Spanish-related origins.
} 
the integration of the industry and the academia in common projects around HCI, relevant people from the Spanish industry were included in the AIPO board. AIPO also collaborated with a exhibition stand at the industrial Internet Global Congress (IGC) in 2006. Concerning the appropriate translation of international ideal values and standards associated with usability, AIPO sponsored the project Iniciativa UsabAIPO (started in 2004 and still underway), which involved the participation of more than 15 university research groups specialized in HCI. The usability of official webs in the context of the Latin-America academia was tested, and some ideal values, metrics, heuristics and Cognitive Walktroughs were proposed [7,8,9].

\section{Looking to the Future: The AIPO Challenges and Trends}

During next years, a central trend in AIPO is related to reinforce the participation of members coming from Latin American countries. As an example, the Colombian branch of AIPO was created in 2007. Besides, a Master in HCI sponsored by AIPO will be started next academic year 2007-2008 at Universitat de Lleida (Spain). Their contents were elaborated following the Bolonia Process ${ }^{3}$ on the basis of the consensus between HCI researchers and professionals coming from the industry, including members of the AIPO board. Different AIPO members (belonging to different universities) are expected to participate as professors in this new Master program.

Acknowledgments. Project ADACO (TIN2004-08000-C03-03)

\section{References}

[1] Granollers, T.: HCI in Spanish speaking countries. IFIP TC 13 Seminar Trends in HCI. Spain (2007)

[2] La Interacción Persona Ordenador, Abascal, J., et al. (eds). AIPO, (Copyright 2001-2006), electronic book available at http://griho.udl.es/ipo/libroe.html ISBN 84-607-2255

[3] Granollers, T., Lorés, J., Cañas, J.J.(eds.): Diseño de Sistemas Interactivos Centrados en el Usuario. Ed. UOC (2005), ISBN 84-9788-320-9

[4] Lorés, J., Granollers, T.: La Ingeniería de la Usabilidad y de la Accesibilidad aplicada al diseño y desarrollo de sitios web. Universitat de Lleida, (2004)

[5] Navarro, R., Lorés, J.: HCI related papers of Interacción'04. Springer, Heidelberg (2005) ISBN 1-4020-4204-3

[6] Presente y Futuro de la Docencia e Inv. en Interacción Persona-Ordenador. Redondo, M., Bravo, C., Lorés, J. (eds.) Linces Artes Gráf. (2005), ISBN 84-689-2758-9

[7] González, M.P., Lorés, J., Granollers, T.: Assessing Usability Problems in Latin-American Academic Webpages with Cognitive Walkthroughs and Datamining Techniques. In: HCII'07, Beijing, China. LNCS, Springer, Heidelberg (2007)

[8] González, M. P., Lorés, J., Pascual, A., Granollers, T.: Evaluación Heurística de Sitios Web Académicos Latinoamericanos dentro de la Iniciativa UsabAIPO. In: Proc. INTERACCION'06, pp. 145-157 (2006) ISBN 84-690-1613

[9] Lorés, J., González, M. P., Pacual, A.: Primera fase de análisis del Proyecto UsabAIPO. In: Paraninfo, Th. (ed.) Proc.INTERACCIÓN'05, pp. 217-221, (2005) ISBN 84-9732-436-6

\footnotetext{
${ }^{3}$ See http://ec.europa.eu/education/policies/educ/bologna/bologna_en.html
} 